Original Research Article

\title{
Assessment of arterial stiffness in stable patients of chronic obstructive pulmonary disease: a prospective case control study
}

\author{
Sandeep Kumar'1, D. D. Gupta ${ }^{1 *}$, Malay $\operatorname{Sarkar}^{2}$, Ramesh ${ }^{1}$
}

\begin{abstract}
${ }^{1}$ Department of Pharmacology, ${ }^{2}$ Department of Pulmonary Medicine, I.G.M.C., Shimla, Himachal Pradesh, India
\end{abstract}

Received: 17 August 2018

Revised: 08 October 2018

Accepted: 13 October 2018

*Correspondence to:

Dr. D. D. Gupta,

Email: drddgupta@

rediffmail.com

Copyright: (C) the author(s), publisher and licensee Medip Academy. This is an openaccess article distributed under the terms of the Creative Commons Attribution NonCommercial License, which permits unrestricted noncommercial use, distribution, and reproduction in any medium, provided the original work is properly cited.

\begin{abstract}
Background: Chronic obstructive pulmonary disease (COPD) is a major cause of morbidity and mortality worldwide and represents a substantial socioeconomic burden. Co-morbidities are more in COPD patients. Cardiovascular disease is one of the co-morbid conditions in COPD. Arterial stiffness has a strong predictive value for cardiovascular events, which can be assessed non-invasively. Various predictors of arterial stiffness between stable COPD patients and healthy volunteers were measured and compared.

Methods: COPD patients attending pulmonary medicine outpatient services were screened for enrolment. It was a prospective case control study with enrolment of fifty COPD stable cases and fifty healthy control, who were matched for their age and sex. All eligible participants were subjected to focused history and physical examination as per structured questionnaire, followed by spirometric examination, periscope test, arterial blood gas analysis and six- minute walk test (6MWT).

Results: Increased arterial stiffness was observed in COPD patients over a wide range of severity of airway obstruction. Distance walked in 6MWT and spirometric values were significantly lower in COPD group as compared to healthy group.

Conclusions: It was concluded that vascular changes, which are predictive of cardiovascular disease remain as cardiovascular risks in mild or early lung disease. A strong relationship between COPD, systemic inflammation, arterial stiffness and cardiovascular disease had been found which needs to be explored further. It was finally concluded that targeted therapeutic approach has broad aspect in reducing cardiovascular risks and has potential for improved prognosis in COPD.
\end{abstract}

Keywords: Arterial stiffness, COPD, Periscope analysis

\section{INTRODUCTION}

Chronic obstructive pulmonary disease (COPD) as a "common, preventable and treatable disease is a major cause of morbidity and mortality worldwide and represents a substantial socioeconomic burden. ${ }^{1}$

The mortality due to COPD is showing an increasing trend. It was the fourth leading cause of death in 1990 and at present, it is the third leading cause of death globally. ${ }^{2}$
Clinically, the disease expresses in combination of chronic bronchitis and emphysema. The natural history of COPD is usually progressive, and patients commonly suffer from exacerbations of the disease. ${ }^{3}$ Comorbidities are increasingly recognized in COPD patients and have significant negative impact on health status, healthcare utilization, all-cause hospital admissions and mortality in COPD patients. ${ }^{4}$ Cardiovascular disease (CVD) is an important comorbid condition in COPD patients. Airflow obstruction profoundly affects cardiac function and gas 
exchange, leading to systemic consequences, chronic inflammation both in lung and cardiovascular system may be associated with endothelial dysfunction, loss of elastin, and eventual vascular calcification. ${ }^{5}$ Carotid intima-media thickness, endothelial function and arterial stiffness measurements are several subclinical markers of CVD that may have a role in identifying early changes in the cardiovascular system before the occurrence of major clinical events, such as myocardial infarction and stroke. ${ }^{6}$ Among these markers, arterial stiffness has a strong predictive value for cardiovascular events beyond that of classic cardiovascular risk factors and is the most suited for use in routine clinical practice. ${ }^{7}$

Arterial stiffness has been independently associated not only with the severity of the COPD but also with inflammation, oxidative stress, and high sympathetic tone, the common processes of development of CVD in COPD patients. ${ }^{8}$ Arterial stiffness is a potentially modifiable risk factor and has added predictive value beyond that obtained from traditional risk factors. ${ }^{9,10}$ Arterial stiffness has been the target of pharmacologic and exercise interventions in patients with COPD. ${ }^{11}$ Assessment of functional exercise capacity has gained importance in the evaluation of patients with various disease states. Six-minute walk test is a simple measure to assess the exercise capacity of patients with cardiopulmonary diseases. ${ }^{12}$

The present study was done to measure the arterial stiffness in stable patients of COPD and also to determine various predictors of increased arterial stiffness in stable COPD patients.

\section{METHODS}

The study was conducted in the Departments of Pulmonary Medicine and Pharmacology at Indira Gandhi Medical College, Shimla, which is a tertiary care center of Himachal Pradesh, located in north India in Asian Continent, which caters the majority of population of this state. A total of fifty patients fulfilling the inclusion and exclusion criteria and fifty healthy controls of similar age group, were enrolled in this study (Figure 1). It was conducted during July 2016 to June 2017. Written informed consent was obtained from all patients and study approval was taken from the Institutional ethical committee. It was a prospective case-control study. All consecutive patients diagnosed to have chronic obstructive pulmonary disease (COPD) and attending pulmonary medicine outpatient services were screened for enrolment in the study.

\section{Inclusion criteria}

- Patients with objectively confirmed stable COPD according to GOLD guidelines and aged 40 years or more.

- Written informed consent from patients willing to participate in the study.

\section{Exclusion criteria}

- History of COPD exacerbation within the last 6 weeks

- COPD patients with history of any cardiovascular disease, hypertension, dyslipidemia and diabetes mellitus were excluded.

- Other lung diseases.

- Inflammatory conditions, such as rheumatoid arthritis or psoriasis; or taking drugs that affect vascular function, including statins, angiotensin-converting enzyme inhibitors and beta-blockers.

- Patients receiving long-term oxygen therapy or corticosteroids.

\section{Data collection}

All eligible patients consenting to participate were subjected to focused history and physical examination as per structured questionnaire to record information related to socio-demographic profiles, duration of symptoms of chronic obstructive pulmonary disease, level of breathlessness using modified Medical Research Council scale (mMRC), history of any cardiovascular disease or peripheral arterial disease. Physical examination to record BP, HR, RR, anthropometrics, weight, height, waist circumference using appropriate tools and following standard guideline and arterial $\mathrm{SaO}_{2}$ was measured with hand-held pulse oximeter.

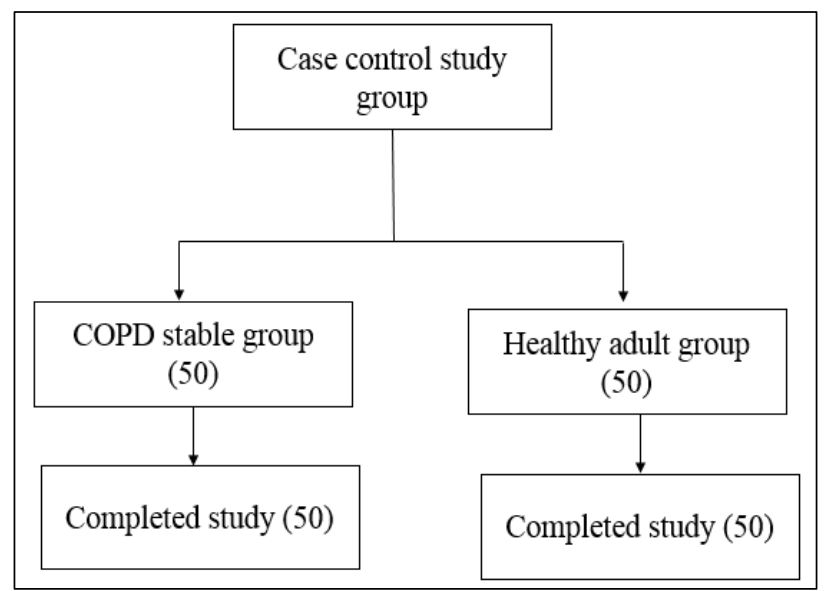

Figure 1: Flow chart of patients participating in study.

\section{Investigations}

Following investigations were carried out in each subject.

\section{Lung function tests}

Spirometric examination was done in all the patients using an electronic portable based spirometer with printer (Model Vitalgraph-Compact-Buckingham, England). It was post-bronchodilator spirometry according to global initiative for chronic obstructive lung disease (GOLD criteria). At least three measurements were made for each lung function variable to ensure reproducibility and 
average measurement was accepted for final analysis. Grading of COPD was done as per GOLD guidelines. The spirometric classification of COPD was divided into four groups based on post-bronchodilator forced expiratory volume in 1 second (FEV1) levels. These are mild (GOLD-1, FEV1 $\geq 80 \%$ of predicted), moderate (GOLD-2, $50 \% \leq \mathrm{FEV} 1<80 \%$ of predicted), severe (GOLD-3, $30 \% \leq \mathrm{FEV} 1<50 \%$ of predicted) and very severe (GOLD4, FEV $1<30 \%$ of predicted).

\section{Periscope test}

Periscope is a PC-based system for analysis of various parameters e.g., Blood Pressure (B.P.), pulse wave velocity (PWV), arterial stiffness Index (ASI), ankle brachial index (ABI), carotid-femoral index, ejection slope, mean arterial pressure (MAP), pulse pressure (PP), $\%$ MAP, ejection time and estimated ejection fraction. These parameters were calculated by measuring blood pressure from four limbs non-invasively and from ECG wave forms.

\section{Arterial blood gas (ABG) analysis}

ABG analysis of arterial blood sample drawn in $2 \mathrm{ml}$ heparinized syringe was done in all subjects in $A B G$ analyzer instrument (Model No. GEM Premier 3000) and arterial $\mathrm{pO}_{2}, \mathrm{pCO}_{2}, \mathrm{pH}$, saturation and bicarbonates were measured.

\section{Six minutes walking test}

The 6 minutes walking test was performed in the department of Pulmonary Medicine, where we used 30 metres long corridor. The test was completed according to the standards of ATS guidelines. The parameters that were recorded during the test included oxygen saturation levels before and after the 6 minutes walking test, the distance that the patients walked over 6 minutes and the lowest and the highest oxygen saturation levels. During the test, a decrease in oxygen saturation level of equal or more than $4 \%$ from the initial level was accepted as desaturation.

\section{Statistical analysis}

SPSS version 23 was used. Continuous variables are presented as the mean $\pm \mathrm{SD}$, and categorical variables are expressed as a percentage. Independent student t-test was used for the continuous variables.

\section{RESULTS}

The present study was conducted on an outpatient basis in the Department of Pulmonary medicine at Indira Gandhi Medical College, Shimla from $1^{\text {st }}$ July 2016 to $30^{\text {th }}$ June 2017. It was a prospective case-control study which evaluated the arterial stiffness in stable patients of chronic obstructive pulmonary disease who attended the outpatient services.
Written informed consent was taken from all the patients. The controls were matched for age and sex. All patients were assessed for clinical examination, spirometry and other investigations. Socio-demographic characteristics including age, sex, level of education and socio-economic status were matched between the groups (Table 1). The percentage of illiterate subject were higher in COPD stable group than healthy adult group $(20 \%$ vs $08 \%)$ p $<0.001$ and urbanization is more common in healthy adult group than COPD stable group (CSG); (37\% vs 10\%), p <0.0001.

The prevalence of current smoking was higher in the COPD patients than among healthy controls (14\% vs $07 \%$ ), $\mathrm{p}<0.0001$.

The smoking index was significantly higher among patients with stable COPD. It was $458.50 \pm 285.48$ in COPD and $145.44 \pm 179.83$ in healthy controls $(\mathrm{p}<0.0001)$.

The percentage difference of exposure to biomass fuel smoke in stable COPD group was $47 \%$. It was $28 \%$ in the healthy controls group, and the difference was statistically significant, $\mathrm{p}<0.0001$. The mean difference in the duration of biomass fuel smoke in two groups was significant (16.62 \pm 8.35 vs $7.70 \pm 7.75), \mathrm{p}<0.0001$.

Most of the participants in COPD stable group were suffering from mMRC class II (27) and mMRC class I (14) dyspnea with minimum number of participants were in mMRCclass III (9) and none in mMRCclass-0, while healthy controls (group 2) exhibited 49, 1, 0 and 0 patients in class 0 , class I, class II and class III respectively. The mean percentage of the cough among the stable COPD group was $49 \%$ vs. $0.00 \%$ in the healthy controls group (p $<0.0001)$.

A total of $39 \%$ had presented with a history of productive cough, while $4 \%$ had a non-productive cough among stable COPD group. Most of the participants in COPD stable group had no cross ventilation in kitchen with only $25 \%$ cross-ventilation versus $41 \%$ cross ventilation in healthy adult group $(\mathrm{p}<0.001)$, which was statistically significant (Table 1).

Anthropometrically, COPD stable patients had lesser height, weight and BMI as compared to healthy group. The difference in mean height was $160.44 \pm 8.29$ versus $164.12 \pm 7.81$ ( $\mathrm{p}<0.025$, statistically significant), whereas difference in mean weight was $54.90 \pm 11.14$ versus $60.54 \pm 10.64$ ( $p<0.011$ statistically significant). However, difference in BMI among two groups was $21.29 \pm 3.79$ vs $22.40 \pm 3.09$ which was not significant statistically $(\mathrm{p}=0.113)$. Mean SBP and DBP was lower in COPD patients as compared to healthy group which were not significant statistically. Average PR $(83.76 \pm 10.87$ vs $79.56 \pm 7.48)$ and average RR (21.68 \pm 2.49 vs $20.22 \pm 1.94)$ had significant difference among two groups with higher values in COPD group (Table 2). 
Table 1: Distribution of clinical characteristics in study groups.

\begin{tabular}{|c|c|c|c|c|}
\hline \multicolumn{2}{|l|}{ Variables } & $\begin{array}{l}\text { Group-1 } \\
\text { COPD stable group }\end{array}$ & $\begin{array}{l}\text { Group-2 } \\
\text { healthy controls }\end{array}$ & P- value \\
\hline \multicolumn{5}{|c|}{ Socio-demographic characteristics } \\
\hline \multirow{4}{*}{ Age } & $40-49$ (years) & $3 \%$ & $3 \%$ & \multirow{4}{*}{0.9} \\
\hline & $50-59$ (years) & $10 \%$ & $10 \%$ & \\
\hline & $60-69$ (years) & $26 \%$ & $27 \%$ & \\
\hline & $>70$ (years) & $11 \%$ & $11 \%$ & \\
\hline \multirow{2}{*}{ Sex } & Male & $34 \%$ & $34 \%$ & \multirow{2}{*}{1.0} \\
\hline & Female & $16 \%$ & $16 \%$ & \\
\hline Urban & & $10 \%$ & $37 \%$ & 0.0001 \\
\hline \multirow{5}{*}{ Education } & Illiterate & 20 & 8 & \multirow{5}{*}{0.001} \\
\hline & Primary & 15 & 7 & \\
\hline & Matriculate & 10 & 16 & \\
\hline & Graduate & 5 & 19 & \\
\hline & Post-Graduate & 0 & 0 & \\
\hline \multirow{3}{*}{ Smoking } & Never & 4 & 23 & \multirow{3}{*}{0.0001} \\
\hline & Ex-smoker & 32 & 20 & \\
\hline & Current Smoker & 14 & 7 & \\
\hline \multicolumn{2}{|l|}{ Smoking index } & $458.50 \pm 285.48$ & $145.44 \pm 179.83$ & 0.0001 \\
\hline \multicolumn{2}{|c|}{ Exposure to biomass fuel } & 47 & 28 & 0.0001 \\
\hline \multirow{3}{*}{$\begin{array}{l}\text { Frequency of } \\
\text { biomass fuel } \\
\text { exposure }\end{array}$} & Occasionally & 6 & 34 & \multirow{3}{*}{0.0001} \\
\hline & Frequently & 23 & 13 & \\
\hline & Daily & 21 & 3 & \\
\hline \multicolumn{2}{|c|}{ Duration of biomass fuel exposure (years) } & $16.62 \pm 8.35$ & $7.70 \pm 7.75$ & 0.0001 \\
\hline \multirow{4}{*}{$\begin{array}{l}\text { mMRC (Modified } \\
\text { Medical Research } \\
\text { Council) Dyspnea } \\
\text { scale }\end{array}$} & mMRC0 & 0 & 49 & \multirow{4}{*}{0.0001} \\
\hline & mMRC1 & 14 & 1 & \\
\hline & mMRC2 & 27 & 0 & \\
\hline & mMRC3 & 9 & 0 & \\
\hline \multicolumn{2}{|l|}{ Cough } & $43 \%$ & $00 \%$ & 0.0001 \\
\hline \multirow{2}{*}{ Type of cough } & Non-productive & 4 & 0 & \multirow{2}{*}{0.0001} \\
\hline & Productive & 39 & 0 & \\
\hline \multicolumn{2}{|c|}{ Duration of cough (months) } & $11.26 \pm 14.50$ & $00 \%$ & 0.0001 \\
\hline \multirow{2}{*}{ Type of kitchen } & Open & 1 & 0 & \multirow{2}{*}{0.35} \\
\hline & Closed & 49 & 50 & \\
\hline \multicolumn{2}{|l|}{ Cross ventilation } & 25 & 41 & 0.001 \\
\hline
\end{tabular}

Table 2: Comparison of anthropometric parameters between COPD stable group and healthy adult group.

\begin{tabular}{|lllll|}
\hline Variables & $\begin{array}{l}\text { COPD stable group } \\
(\mathbf{n}-\mathbf{5 0})\end{array}$ & $\begin{array}{l}\text { Healthy controls } \\
(\mathbf{n}-\mathbf{5 0})\end{array}$ & Mean difference (95\% C.I.) & P value \\
\hline Height $(\mathrm{cm})$ & $160.44 \pm 8.29$ & $164.12 \pm 7.81$ & $-3.68(-6.87$ to -.48$)$ & 0.025 \\
\hline Weight $(\mathrm{kg})$ & $54.90 \pm 11.14$ & $60.54 \pm 10.64$ & $-5.64(-9.96$ to -1.31$)$ & 0.011 \\
\hline BMI & $21.29 \pm 3.79$ & $22.40 \pm 3.09$ & $-1.106(-2.48$ to .267$)$ & 0.113 \\
\hline PR & $83.76 \pm 10.87$ & $79.56 \pm 7.48$ & $4.20(0.49$ to 7.90$)$ & 0.027 \\
\hline SBP & $123.28 \pm 9.77$ & $124.80 \pm 9.18$ & $-1.52(-5.28$ to 2.24$)$ & 0.425 \\
\hline DBP & $77.12 \pm 6.02$ & $78.44 \pm 5.22$ & $-1.32(-3.55$ to .917$)$ & 0.245 \\
\hline RR & $21.68 \pm 2.49$ & $20.22 \pm 1.94$ & $1.46(0.57$ to 2.34$)$ & 0.002 \\
\hline
\end{tabular}

BMI=Body mass index, $\mathrm{PR}=$ Pulse rate, $\mathrm{SBP}=$ Systolic blood pressure, $\mathrm{DBP}=$ Diastolic blood pressure, $\mathrm{RR}=$ Respiratory rate.

In present study, pulmonary function test showed decreased lung volume and lung capacity in COPD group. These parameters were recorded as SVC $(62.38 \pm 12.34$ vs
86.78 \pm 7.58$)$; FVC (63.02 \pm 14.87 vs $88.50 \pm 9.80)$; FEV1 $(60.34 \pm 17.56$ vs $89.78 \pm 8.60) ; \mathrm{FEF}_{25-75 \%}(37.92 \pm 24.12$ vs 98.94 \pm 16.66$)$ and FEV1/FVC $\quad(94.78 \pm 15.05$ vs $101.60 \pm 9.57)$. 
All these parameters showed significant difference ( $p$ $<0.0001$ ) among two groups (Table 3). Different variables of periscope analysis and their comparison among two groups had been shown in Table 4. There was significant difference in all the variables of periscope analysis between two groups. The mean of 6MWT in COPD stable group was $286.90 \pm 46$ versus $399.38 \pm 28.4$ in the healthy adult group, mean of $\mathrm{SPO}_{2}$ at rest was $88.20 \pm 2.75$ versus
$95.76 \pm 1.27$, mean of SPO2 after 6MWT was $80.38 \pm 2.91$ versus $95 \pm 1.21$. The mean $\mathrm{HR}$ at rest was $83.78 \pm 10.75$ versus $79.56 \pm 7.48$. The mean of HR after 6MWT in COPD stable group was 93.24 \pm 11.35 versus $86.24 \pm 7.77$ in the healthy adult group. All variables of 6MWT had significant difference among two groups (Table 5).

Table 3: Comparison of pulmonary function test between COPD stable group and healthy adult group.

\begin{tabular}{|lllll|}
\hline Characteristics & $\begin{array}{l}\text { COPD stable } \\
\text { group }(\mathbf{n}-\mathbf{5 0})\end{array}$ & $\begin{array}{l}\text { Healthy controls } \\
(\mathbf{n}-50)\end{array}$ & Mean difference (95\% C.I.) & P value \\
\hline SVC (\%predicted) & $62.38 \pm 12.34$ & $86.78 \pm 7.58$ & $-24.4(-28.46$ to -20.33$)$ & 0.000 \\
\hline FVC (\%predicted) & $63.02 \pm 14.87$ & $88.50 \pm 9.80$ & $-25.48(-30.48$ to -20.47$)$ & $<0.001$ \\
\hline FEV $_{1}$ (\%predicted) & $60.34 \pm 17.56$ & $89.78 \pm 8.60$ & $-29.44(-34.92$ to -23.95$)$ & 0.000 \\
\hline FEF $_{25-75 \%(\% \text { predicted) }}$ (\%) & $37.92 \pm 24.12$ & $98.94 \pm 16.66$ & $-61.02(-69.24$ to -52.79$)$ & 0.000 \\
\hline FEV $_{1} /$ FVC $(\%$ predicted) & $94.78 \pm 15.05$ & $101.60 \pm 9.57$ & $-6.82(-11.82$ to -1.81$)$ & 0.008 \\
\hline
\end{tabular}

$\mathrm{SVC}=$ Slow vital capacity, $\mathrm{FVC}=$ Forced vital capacity, FEV1=Forced expiration volume in one second, FEF25-75\%=Flow expiratory flow 25 to $75 \%$.

Table 4: Comparison of arterial stiffness between COPD stable group and healthy adult group.

\begin{tabular}{|lllll|}
\hline Variables & $\begin{array}{l}\text { COPD stable group } \\
(\mathbf{n}-50)\end{array}$ & $\begin{array}{l}\text { Healthy controls } \\
(\mathbf{n}-50)\end{array}$ & $\begin{array}{l}\text { Mean difference } \\
\text { (95\% C.I.) }\end{array}$ & P value \\
\hline RBAPWV $(\mathrm{cm} / \mathrm{s})$ & $1600.51 \pm 682.61$ & $1267.34 \pm 358.82$ & $333.17(116.74$ to 549.60$)$ & 0.003 \\
\hline LBAPWV $(\mathrm{cm} / \mathrm{s})$ & $1458.49 \pm 804.58$ & $995.55 \pm 451.32$ & $462.94(204.03$ to 721.84) & 0.001 \\
\hline c-fPWV $(\mathrm{cm} / \mathrm{s})$ & $964.02 \pm 555.94$ & $782.07 \pm 212.68$ & $181.94(14.89$ to 348.99) & 0.033 \\
\hline RBASI $(\mathrm{mmHg})$ & $32.25 \pm 10.80$ & $25.92 \pm 6.24$ & $6.32(2.82$ to 9.83$)$ & 0.001 \\
\hline LBASI $(\mathrm{mmHg})$ & $33.17 \pm 14.52$ & $26.28 \pm 7.92$ & $6.88(2.24$ to 11.53) & 0.004 \\
\hline RAASI $(\mathrm{mmHg})$ & $40.18 \pm 12.16$ & $35.35 \pm 8.74$ & $4.83(0.63$ to 9.04) & 0.025 \\
\hline LAASI $(\mathrm{mmHg})$ & $42.34 \pm 12.82$ & $39.10 \pm 8.69$ & $3.23(-1.11$ to 7.58$)$ & 0.143 \\
\hline ABI & $1.075 \pm .081$ & $1.106 \pm .082$ & $-.0314(-0.0639$ to .00116$)$ & 0.059 \\
\hline
\end{tabular}

RBAPWV=Right brachial ankle pulse wave velocity, LBAPWV=Left brachial ankle pulse wave velocity, c-fPWV=Carotid femoral pulse wave velocity, RBASI=Right brachial arterial stiffness index, LBASI=Left brachial arterial stiffness index, RAASI=Right ankle arterial stiffness index, LAASI=Left ankle arterial stiffness index, ABI=Ankle brachial index.

Table 5: Comparison of various distribution of 6-minute walk test on COPD stable group and healthy adult group.

\begin{tabular}{|lllll|}
\hline Characteristics & $\begin{array}{l}\text { COPD stable } \\
\text { group }(\mathbf{n}-50)\end{array}$ & $\begin{array}{l}\text { Healthy controls } \\
(\mathbf{n}-50)\end{array}$ & $\begin{array}{l}\text { Mean difference } \\
\text { (95\% C.I.) }\end{array}$ & P value \\
\hline 6MWT & $286.90 \pm 46$ & $399.38 \pm 28.4$ & $-112.48(-127.65$ to -97.30$)$ & 0.000 \\
\hline $\mathrm{SPO}_{2}$ at rest & $88.20 \pm 2.75$ & $95.76 \pm 1.27$ & $-7.56(-8.41$ to -6.70$)$ & 0.000 \\
\hline $\mathrm{SPO}_{2}$ after 6MWT & $80.38 \pm 2.91$ & $95 \pm 1.21$ & $-14.62(-15.50$ to -13.73$)$ & $<0.001$ \\
\hline $\mathrm{HR}$ at rest & $83.78 \pm 10.75$ & $79.56 \pm 7.48$ & $4.22(0.542$ to 7.89$)$ & 0.025 \\
\hline HR after 6MWT & $93.24 \pm 11.35$ & $86.24 \pm 7.77$ & $7(3.13$ to 10.86$)$ & 0.001 \\
\hline
\end{tabular}

$6 \mathrm{MWT}=$ Six minutes walk test, $\mathrm{SPO}_{2}=\mathrm{Blood}$ oxygen saturation

Patients of COPD, when stratified by global Initiative for chronic obstructive lung disease (GOLD) stage, 4\% patients were in stage I, $31 \%$ were in stage II, $13 \%$ stage III and $2 \%$ stage IV (Figure 2). The mean of $\mathrm{pH}$ in COPD stable group was $7.41 \pm 0.04$ versus $7.37 \pm 0.03$ in the healthy adult group $(\mathrm{p}<0.000)$ with mean difference (CI 95\%) of 0.035 (.0209 to 0.0498$)$, which was statistically significant. The mean of $\mathrm{PCO}_{2}$ in $\mathrm{COPD}$ stable group was
$43.67 \pm 7.22$ versus $39.72 \pm 2.54$ in the healthy adult group $\mathrm{p}<0.001$ with mean difference (CI 95\%) of 3.94 (1.795 to 6.092), which was statistically significant. The mean of $\mathrm{PO}_{2}$ in COPD stable group was $48.57 \pm 8.64$ versus $89.49 \pm 4.64$ in the healthy adult group $(\mathrm{p}<0.000)$ with mean difference (CI 95\%) of -40.9 (-43.670 to -38.165$)$, which was statistically significant. The mean of $\mathrm{SPO}_{2}$ in $\mathrm{COPD}$ stable group was $88.44 \pm 2.54$ versus $95.76 \pm 1.27$ in the 
healthy adult group $(\mathrm{p}<0.000)$, mean difference (CI 95\%) of $-7.32(-8.117$ to -6.522$)$, which was statistically significant (Figure 3).

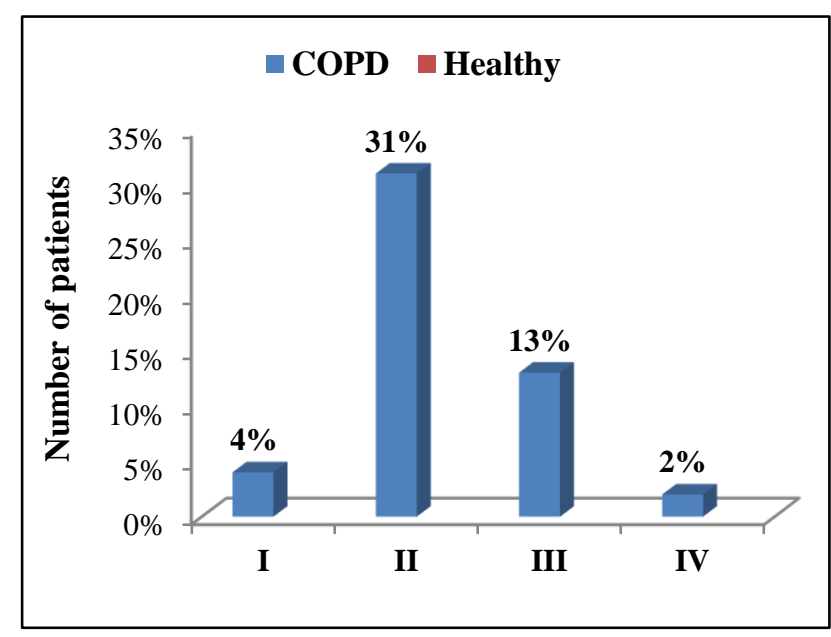

Figure 2: GOLD criteria staging of COPD stable group patients.

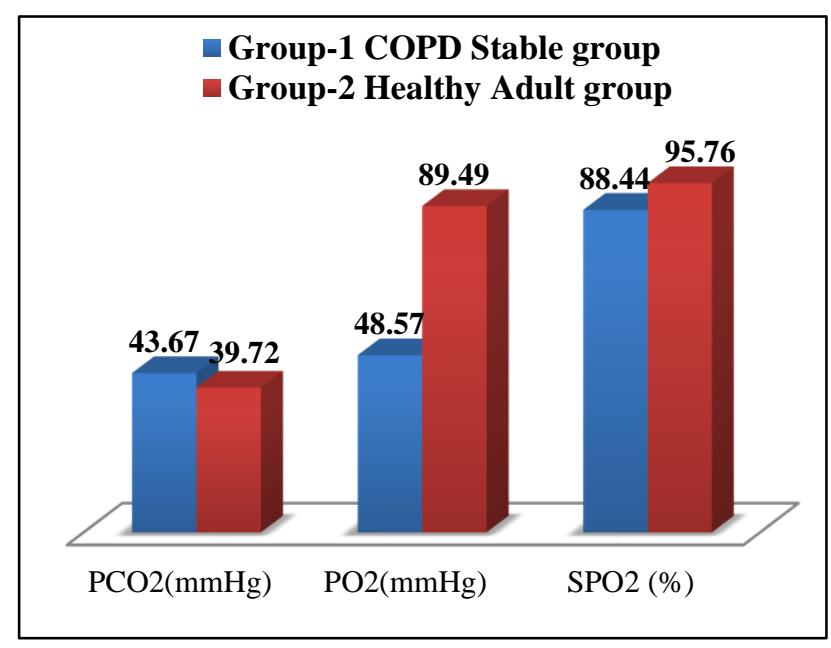

Figure 3: Comparison of ABG between two study groups.

Urbanization is related to well education and better awareness to cross ventilation among two groups. However, because of urbanization, exposure to tobacco product and biofuel along with increment in BMI were higher in the study group as compared to control group.

Level of education contributes in development of arterial stiffness as the knowledge regarding exposure to biofuel and tobacco was lowest when the population is illiterate.

\section{DISCUSSION}

A close connection exists between COPD and cardiovascular diseases Arterial pulse wave velocity (PWV) constitutes a useful and safe non-invasive method for assessing central arterial stiffness. ${ }^{6,13}$
In present study, majority of COPD patients were from the rural background and only $10 \%$ of the COPD patients resided in the urban locality. Another reason for rural predominance could be the widespread use of biomass combustion as cooking medium in the hilly rural areas. Illiteracy rate was also higher among the COPD patients ( $20 \%$ vs. $08 \%$ ); p $<0.001$ compared to healthy control. These results correlated to other studies. ${ }^{14,15}$

Exposure to biomass fuel smoke (47\% vs $28 \%$ ), use of tobacco product (14\% vs $07 \%$ ) and mean smoking index $(458.50 \pm 285.48$ vs $145.44 \pm 179.83)$ were significantly higher $(\mathrm{p}<0.0001)$ in COPD patients as compared to the control group (Table 1). These results were also correlated to some other studies. ${ }^{14,16}$

Higher rate of pulse and respiration is usual in COPD patients. In the Copenhagen city heart study, which was a prospective population based study it was found that, resting heart rate increased with severity of COPD $(\mathrm{p}<0.001)$ and was associated with both cardiovascular and all cause mortality across all stages of COPD $(\mathrm{p}<0.001) .{ }^{17}$ Similar trend had been observed in present study where pulse rate $(83.76 \pm 10.87$ vs. $79.56 \pm 7.48)$ and respiratory rate $(21.68 \pm 2.49$ vs. $20.22 \pm 1.94)$ demonstrated significant difference among two groups $(\mathrm{p}<0.001)$ (Table 2). It could be because of airwday obstruction, hyperinflation and hypoxemia.

Decreased values SVC, FVC, $\mathrm{FEV}_{1}, \mathrm{FEF}_{25-75 \%}$ and $\mathrm{FEV}_{1} /$ FVC in COPD group had significant difference $(p<0.0001)$ in comparison to healthy group (Table 3). It was in concordance with the previous studies which showed that patients of COPD had significant reduction in spirometric values as shown in the studies. ${ }^{18,19}$

Amongst different variables of periscope analysis, the mean of RBAPWV, LBAPWV and c-fPWV was significantly higher in the COPD stable group as compared to healthy control group ( $\mathrm{p}<0.05$ ). The mean of RBASI, LBASI and RAASI in COPD stable group was higher than in healthy control group and they found to be highly significant with a p-value for RBASI, LBASI and RAASI being $0.001,0.004$ and 0.025 respectively (Table 4 ). These enhanced levels of various variables in our study group are indicative of increased arterial stiffness. These results have positive correlation with some other studies. ${ }^{20-22}$

In COPD stable group, $\mathrm{ABG}$ parameters such as $\mathrm{pH}$ $(7.41 \pm 0.04$ vs $7.37 \pm 0.03) ; \mathrm{p}<0.0001, \quad \mathrm{PCO}_{2}(\mathrm{mmHg})$ (43.67 \pm 7.22 vs $39.72 \pm 2.54) ; \mathrm{p}<0.0001, \quad \mathrm{PO}_{2}(\mathrm{mmHg})$ $(48.57 \pm 8.64$ vs $89.49 \pm 4.64) ; \quad \mathrm{p}<0.0001, \quad \mathrm{SPO}_{2} \quad(\%)$ $(88.44 \pm 2.54$ vs $95.76 \pm 1.27) ; \mathrm{p}<0.0001$ were significantly impaired as compared to the control group. These results have positive correlation with some other studies. ${ }^{23,24}$

The main contributing factors consistently reported for arterial stiffness are aging, smoking, BP, metabolic disorders, chronic inflammation, and oxidative stress. Airflow obstruction has been an independent predictor of 
arterial stiffness in COPD. In a cross-sectional study involving 194 men, aged 30-70 years, who were free of coronary heart diseases, suggesting that both obstructive and restrictive lung disorders are associated with increased arterial stiffness. $^{25}$

Arterial stiffness was increased even with a mild degree of airway obstruction, indicating its early occurrence in the natural history of COPD ${ }^{8}$ In a cross-sectional study, Sabit et al, measured arterial stiffness in 75 clinically stable COPD patients and 42 healthy current or ex-smoking participants. All participants were free of CVD. Both PWV and augmentation index (Alx) were significantly higher in COPD patients than in age matched controls. Increased aortic PWV was related to increased severity of airflow obstruction, systemic inflammation, and the presence of osteoporosis.

One possible explanation for low lung function and arterial stiffness could be an alteration of elastolytic activity in both the alveoli and the vasculature. Elastolysis in COPD can occur in both the pulmonary and systemic levels. ${ }^{6}$

In the present study, there were some predictors, which positively correlate the increased incidence of arterial stiffness. Subject who exposed to the tobacco product had higher incidence of mMRC $(\mathrm{p}<0.005)$. Urbanization is related to improvement in education $(\mathrm{p}<0.005)$ and those who had good educational background were less prone to develop cough $(\mathrm{p}<0.005)$ and related illness, but the urbanization also leads to obesity ( $p<0.005)$, that is another positive indicator to develop oxidative stress, that might also propagate arterial stiffness. Direct relationship was observed between cross ventilation and development of arterial stiffness with inclusion of mMRC and cough as predictors. Subjects who didn't had cross ventilation at their home gets higher incidence of cough ( $\mathrm{p}<0.005)$, and severe mMRC scale $(\mathrm{p}<0.005)$ than those who had cross ventilation, which eventually culminate in development of arterial stiffness.

In the present study, there was significant correlation of the development of arterial stiffness with lifestyle and type of living. Most of the patients were illiterate who exposed themselves to the tobacco products, poor cross ventilation. It is clearly stated that, education and the living standard affect the development of arterial stiffness. This relationship was correlated with some other studies. ${ }^{26-28}$

Present study exhibited marked decrease in oxygen saturation at rest as well as after 6MWT in COPD stable group as compared to control group, also distance covered during 6MWT was severely affected in COPD group. It was in concordance with the earlier studies conducted by Miyamoto et al, which stated that 6MWT distance below 332 metre is an indicator of poor prognosis in cardiovascular diseases. ${ }^{29}$ Another study says that 6MWT has prognostic value in disease severity and mortality in patients with heart diseases. ${ }^{30}$

\section{CONCLUSION}

It was concluded that vascular changes, which are predictive of cardiovascular disease remain as cardiovascular risks in mild or early lung disease. A strong relationship between COPD, systemic inflammation, arterial stiffness and cardiovascular disease had been found which needs to be explored further. It was finally concluded that targeted therapeutic approach has broad aspect in reducing cardiovascular risks and has potential for improved prognosis in COPD.

Funding: No funding sources

Conflict of interest: None declared

Ethical approval: The study was approved by the Institutional Ethics Committee

\section{REFERENCES}

1. Global Strategy for the Diagnosis, Management and Prevention of COPD. Global Initiative for Chronic Obstructive Lung Disease (GOLD); 2017. Available at: http://www.goldcopd.org/. Accessed March 15, 2017.

2. Lozano R, Naghavi M, Foreman K, Lim S, Shibuya K, Aboyans V, et al. Global and regional mortality from 235 causes of death for 20 age groups in 1990 and 2010: a systematic analysis for the Global Burden of Disease Study 2010. Lancet. 2012 Dec 15;380(9859):2095-128.

3. Mannino DM, Thorn D, Swensen A, Holguin F. Prevalence and outcomes of diabetes, hypertension, and cardiovascular disease in chronic obstructive pulmonary disease. European Resp J. 2008 Jun 25.

4. Divo M, Cote C, de Torres JP, Casanova C, Marin JM, Pinto-Plata V, et al. Comorbidities and risk of mortality in patients with chronic obstructive pulmonary disease. Am J Resp Critical Care Med. 2012 Jul 15;186(2):155-61.

5. Lange P, Mogelvang R, Marott JL, Vestbo J, Jensen JS. Cardiovascular morbidity in COPD: a study of the general population. COPD. J Chronic Obstructive Pulmonary Dis. 2011 Feb 1;7(1):5-10.

6. McAllister DA, Maclay JD, Mills NL, Mair G, Miller J, Anderson D, et al. Arterial stiffness is independently associated with emphysema severity in patients with chronic obstructive pulmonary disease. Am J Resp Critical Care Med. 2007 Dec 15;176(12):1208-14.

7. Laurent S, Alivon M, Beaussier H, Boutouyrie P. Aortic stiffness as a tissue biomarker for predicting future cardiovascular events in asymptomatic hypertensive subjects. Ann Med. 2012 Jun 1;44(sup1):S93-7.

8. Sabit R, Bolton CE, Edwards PH, Pettit RJ, Evans WD, McEniery CM, et al. Arterial stiffness and osteoporosis in chronic obstructive pulmonary disease. Am J Resp Critical Care Med. 2007 Jun 15;175(12):1259-65.

9. Yeboah J, McClelland RL, Polonsky TS, Burke GL, Sibley CT, O'leary D, et al. Comparison of novel risk 
markers for improvement in cardiovascular risk assessment in intermediate-risk individuals. JAMA. 2012 Aug 22;308(8):788-95.

10. Sweileh WM. A prospective comparative study of gentamicin and Amikacin induced nephrotoxicity in patients with normal baseline renal function. Fundam Clin Pharmacol. 2009;23(4):515-20.

11. van Popele NM, Grobbee DE, Bots ML, Asmar R, Topouchian J, Reneman RS, et al. Association between arterial stiffness and atherosclerosis: the Rotterdam Study. Stroke. 2001 Feb;32(2):454-60.

12. Vivodtzev I, Minet C, Wuyam B, Borel JC, Vottero G, Monneret D, et al. Significant improvement in arterial stiffness after endurance training in patients with COPD. Chest. 2010 Mar 1;137(3):585-92.

13. Butland RJ, Pang JA, Gross ER, Woodcock AA, Geddes DM. Two-, six-, and 12-minute walking tests in respiratory disease. Br Med J (Clinical research ed.). 1982 May 29;284(6329):1607.

14. Kumar S, Muniyandi M, Kumar D, Pandey M, Soan V, Rajasubramaniam S. Chronic Obstructive Pulmonary Disease: Understanding and Promoting Healthy Lifestyle among Gond Tribe in Madhya Pradesh, India. Int J Curr Microbiol App Sci. 2016;5(10):27-32.

15. Jindal SK, Aggarwal AN, Gupta D. Disease and its association with smoking. Indian J Chest Dis Allied Sci. 2001;43:139-471.

16. Jindal SK, Aggarwal AN, Chaudhry K, Chhabra SK, D Souza GA, Gupta D, et al. A multicentric study on epidemiology of chronic obstructive pulmonary disease and its relationship with tobacco smoking and environmental tobacco smoke exposure. Indian $\mathrm{J}$ Chest Dis Allied Sci. 2006 Jan;48(1):23.

17. Jensen MT, Marott JL, Lange P, Vestbo J, Schnohr P, Nielsen OW, et al. Resting heart rate is a predictor of mortality in COPD. European Resp J. 2013 Aug $1 ; 42(2): 341-9$.

18. Janner JH, McAllister DA, Godtfredsen NS, Prescott E, Vestbo J. Is chronic obstructive pulmonary disease associatedwith increased arterial stiffness? Resp Med. 2012;106:397-405.

19. Sin DD, Wu L, Man SP. The relationship between reduced lung function and cardiovascular mortality: a population-based study and a systematic review of the literature. Chest. 2005 Jun 1;127(6):1952-9.

20. Kool MJ, Hoeks AP, Boudier HA, Reneman RS, Van Bortel LM. Short and long-term effects of smoking on arterial wall properties in habitual smokers. J Am Coll Cardiol. 1993 Dec 1;22(7):1881-6.

21. Failla M, Grappiolo A, Carugo S, Calchera I, Giannattasio C, Mancia G. Effects of cigarette smoking on carotid and radial artery distensibility. J Hypertension. 1997 Dec 1;15(12):1659-64.

22. Hartmann G, Tschöp M, Fischer R, Bidlingmaier C, Riepl R, Tschöp K, et al. High altitude increases circulating interleukin-6, interleukin-1 receptor antagonist and C-reactive protein. Cytokine. $2000 \mathrm{Mar}$ 1;12(3):246-52.

23. Cinarka H, Kayhan S, Gumus A, Durakoglugil ME, Erdogan T, Ezberci I, et al. Arterial stiffness measured via carotid femoral pulse wave velocity is associated with disease severity in COPD. Respiratory Care. 2014 Feb 1;59(2):274-80.

24. Camillo CA, Pitta F, Possani HV. Heart rate variability and disease characteristics in patients with COPD. Lung. 2008;186(6):393-401.

25. Zureik M, Benetos A, Neukirch C, Courbon D, Bean $\mathrm{K}$, Thomas $\mathrm{F}$, et al. Reduced pulmonary function is associated with central arterial stiffness in men. Am J Resp Critical Care Med. 2001 Dec 15;164(12):21815.

26. Iwamoto H, Yokoyama A, Kitahara Y, Ishikawa N, Haruta Y, Yamane K, et al. Airflow limitation in smokers is associated with subclinical atherosclerosis. Am J Resp Critical Care Med. 2009 Jan 1;179(1):3540 .

27. Barr RG, Ahmed FS, Carr JJ, Hoffman EA, Jiang R, Kawut SM, et al. Subclinical atherosclerosis, airflow obstruction and emphysema: the MESA lung study. Eur Resp J. 2012 Apr 1;39(4):846-54.

28. Schroeder EB, Welch VL, Evans GW, Heiss G. Impaired lung function and subclinical atherosclerosis: the ARIC study. Atherosclerosis. 2005 Jun 1;180(2):367-73

29. Miyamoto S, Nagaya N, Satoh T, Kyotani S, Sakamaki F, Fujita M, et al. Clinical correlates and prognostic significance of six-minute walk test in patients with primary pulmonary hypertension: comparison with cardiopulmonary exercise testing. Am J Resp Critical Care Med. 2000 Feb 1;161(2):48792.

30. Britto RR, Probst VS, Andrade AF, Samora GA, Hernandes NA, Marinho PE, et al. Reference equations for the six-minute walk distance based on a Brazilian multicenter study. Brazilian J Physical Therapy. 2013 Dec;17(6):556-63.

Cite this article as: Kumar S, Gupta DD, Sarkar M, Ramesh. Assessment of arterial stiffness in stable patients of chronic obstructive pulmonary disease: a prospective case control study. Int $\mathrm{J}$ Basic Clin Pharmacol 2018;7:2078-85. 